\title{
The use of Bituminaria Bituminosa (L.) Stirton and Microbial Biotechnologies for Restoration of Degraded Pastoral Lands: The Case of the Middle Atlas of Morocco
}

\author{
O. Zennouhi", M . El Mderssa, J. Ibijbijen, E. Bouiamrine, L. Nassiri \\ Soil and Environment Microbiology Unit, Faculty of Sciences, Moulay Ismail University, 11201 Meknes, \\ Morocco
}

*Corresponding Author: O. Zennouhi, Soil and Environment Microbiology Unit, Faculty of Sciences, Moulay Ismail University, 11201 Meknes, Morocco

\begin{abstract}
Rangelands and silvopastoral systems of the middle Atlas are under a heavy pressure, which led to pasture degradation, invasion by non-palatable and toxic species and edaphic aridification due to the regression of the global vegetation cover. In this situation, the introduction of multipurpose leguminous shrubs, such as Bituminaria bituminosa (L.) Stirton, commonly known as bituminous clover, could be a promising socio-ecological alternative for the rehabilitation of these degraded areas. The application of biofertilizers like plant growth promoting rhizobacteria especially phosphate solubilizing bacteria (PSB) can ensure a successful installation of this plant in the selected degraded areas. The main objective of the present work is to produce well-inoculated seedlings using the best efficient PSB strains in the greenhouse to increase their ability to resist to environmental constraints once transplanted to the field in the central Middle Atlas.
\end{abstract}

Keywords: Biofertilizers, Bituminaria bituminosa, phosphate solubilizing bacteria, rehabilitation.

\section{INTRODUCTION}

Forests are the largest deposit of terrestrial biodiversity in the world. In particular in Morocco forests represent 9 million ha which is used by a population [1]. They play a vital role in mitigating global climate change and contribute to soil conservation and many fragile ecosystems. In addition, forests contribute significantly to food security.

The degradation of rangelands has been accentuated over the years leading to a loss of biomass and to the alteration of the biodiversity of plant species. Overgrazing and climate change, including the high frequency of drought years, are among the factors responsible for the low productivity and regenerative capacity of the canopy. The department of Forestry said that the pastoral charge exceeds 3 to 4 times the optimal load [1]. And this estimated shortfall of more than $30 \%$ explains the sharp deterioration of forestry capital. This situation requires the establishment of a reconciling alternative between forage requirements and the rehabilitation of degraded lands. The main objective of this work is to propose a management model using a sustainable biological approach such as the use of droughtadapted leguminous shrubs and low soil fertility.

Leguminous shrubs like Bituminaria bituminosa are important in Morocco; they can make a major contribution to restoring and improving soil fertility and in combating erosion and desertification as well as providing forage for animals. Bituminaria bituminosa especially is widely distributed in the Mediterranean Basin and Macaronesia islands. From the microbiological side, it was reported that dual inoculation with Rhizobium and Mycorrhizal fungi in the nursery contribute in producing high quality seedling of this shrub, which can facilitate their establishment when transplanted in the field [2].

Many studies conducted on the germination process and rate of this plant showed a large variability. The heat and smoke significantly stimulate the rate and the level of the germination. The modification of germination behavior is greatest in the species that normally have an intermediate or high natural germination level [3]-[5]. 
The use of Bituminaria Bituminosa (L.) Stirton and Microbial Biotechnologies for Restoration of Degraded Pastoral Lands: The Case of the Middle Atlas of Morocco

Dry period has extended in recent years especially in summer, it is necessary to keep forage plants such as Bituminaria bituminosa which is one of the rare plant species which can stay green in summer; this can constitute a very good alternative as forage plant in the semi-arid and arid zones table I.

The perennial plant Bituminaria bituminosa offers very nutritious feed to animals with its fruits and seeds as well [7]. And also it supplies nitrogen to the soil and protects the soil against erosion and therefore, it significantly enhances the productivity of soil [8].The mean organic matter of B.bituminosa was 910 , its neutral detergent fiber was 424 and protein content was $184(\mathrm{~g} \mathrm{~kg}-1$ dry matter (DM) table II. However, B.bituminosa had only traces of tannin content ( $\mathrm{g}$ catequins $\mathrm{kg}-1$ DM).The mean ruminal organic matter degradability was $57.5 \%$, protein degradability was $72.2 \%$ and in vitro organic matter digestibility was $64.6 \%$ [6]. Its mean calcium content ( $k g-1 \mathrm{DM})$ was moderate for B. bituminosa (range 10.4-14.3g). Mean phosphorus content of B. bituminosa was 1.5$2.8 \mathrm{~g} \mathrm{~kg}-1 \mathrm{DM}[6]$. Therefore, the net energy content of B. bituminosa was estimated to be 5.6 MJ $\mathrm{kg}-1 \mathrm{DM}$, with significant differences among species and seasons.

B.bituminosa is endemic forages shrub from Canary Islands [9]. Although this species has been widely used in ruminant feed, scarce research has been carried out to determine its nutritive value [10] , [11].Table III .Thus, the objective of this study is to evaluate in the first step, the DM production of this leguminous shrub and therefore the consequences on the soil fertility and the rehabilitation of degraded lands.

Table1. chemical Composition ( $\left.\mathrm{kgg}^{-1} \mathrm{Dm}\right)$ Of B. Bituminosa [6]

\begin{tabular}{|c|c|c|c|c|c|c|}
\hline Time & DM & OM & CP & NDF & ADF & ADL \\
\hline Spring & $311 \mathrm{a}$ & $915 \mathrm{a}, \mathrm{b}$ & $198 \mathrm{a}$ & $380 \mathrm{~b}$ & $256 \mathrm{~b}$ & $52 \mathrm{~b}$ \\
\hline Summer & $266 \mathrm{a}, \mathrm{b}$ & $911 \mathrm{a}, \mathrm{b}$ & $159 \mathrm{~b}$ & $417 \mathrm{a}, \mathrm{b}$ & $223 \mathrm{a}$ & $59 \mathrm{~b}$ \\
\hline Autumn & $270 \mathrm{~b}$ & $890 \mathrm{~b}$ & $204 \mathrm{a}$ & $481 \mathrm{a}$ & $368 \mathrm{a}$ & $82 \mathrm{a}, \mathrm{b}$ \\
\hline Winter & $247 \mathrm{~b}$ & $925 \mathrm{a}$ & $173 \mathrm{a}, \mathrm{b}$ & $416 \mathrm{a}, \mathrm{b}$ & $283 \mathrm{~b}$ & $98 \mathrm{a}$ \\
\hline Mean & $247 \pm 23$ & $910 \pm 13$ & $184 \pm 18$ & $424 \pm 36$ & $296 \pm 52$ & $73 \pm 18$ \\
\hline
\end{tabular}

Table2. Mineral ( $\mathrm{gg}-1 \mathrm{DM}$ ) and Tannin Contents ( $\mathrm{g}$ Catequins $\mathrm{kg}-1$ DM) of B. bituminosa [6]

\begin{tabular}{|c|c|c|c|c|c|c|}
\hline Time & Ca & $\mathbf{P}$ & $\mathbf{M g}$ & $\mathbf{N a}$ & $\mathbf{K}$ & Tannins \\
\hline Spring & $11.3 \mathrm{a}$ & 2.6 & $2.2 \mathrm{a}, \mathrm{b}$ & 2.5 & $26.6 \mathrm{~b}$ & \\
\hline Summer & 10.6 & 2.5 & $1.8 \mathrm{a}, \mathrm{b}$ & 2.4 & $32.2 \mathrm{a}$ & \\
\hline Autumn & 11.0 & 3.1 & $2.6 \mathrm{a}$ & 2.7 & $29.8 \mathrm{a}, \mathrm{b}$ & \\
\hline Winter & 8.6 & 3.2 & $1.6 \mathrm{~b}$ & 3.0 & $33.3 \mathrm{a}$ & \\
\hline Mean & $10.4 \pm 1.0$ & $2.8 \pm 0.3$ & $2.0 \pm 0.4$ & $2.6 \pm 0.2$ & $30.3 \pm 2.6$ & $0.02 \pm 0.004$ \\
\hline
\end{tabular}

Table3. Organic Matter and Protein Ruminal Degradability (Omd, Cpd, \%) In Vitro Dm and Organic Matter Digestibility ( Ivdmd, Ivomd.\%), Digestible Organic Matter (Dom G Kg-1 Dm) and Estimated Net Energy Content (Ne, Mj Kg-1 Md) Of B. Bituminosa[6]

\begin{tabular}{|c|c|c|c|c|c|c|}
\hline Time & OMD & CPD & IVDMD & IVOMD & DOM & NE \\
\hline Spring & $56.2 \mathrm{~b}$ & $70.5 \mathrm{~b}, \mathrm{c}$ & $68.2 \mathrm{a}, \mathrm{b}$ & $65.1 \mathrm{a}$ & $595 \mathrm{a}$ & $5.7 \mathrm{a}$ \\
\hline Summer & $47.7 \mathrm{c}$ & $66.5 \mathrm{c}$ & $68.9 \mathrm{a}, \mathrm{b}$ & $65.9 \mathrm{a}$ & $600 \mathrm{a}$ & $5.7 \mathrm{a}$ \\
\hline Autumn & $58.7 \mathrm{~b}$ & $74.2 \mathrm{a}, \mathrm{b}$ & $63.7 \mathrm{~b}$ & $59.2 \mathrm{~b}$ & $527 \mathrm{~b}$ & $5.1 \mathrm{~b}$ \\
\hline Winter & $67.5 \mathrm{a}$ & $77.6 \mathrm{a}$ & $70.6 \mathrm{a}$ & $68.2 \mathrm{a}$ & $631 \mathrm{a}$ & $6.0 \mathrm{a}$ \\
\hline Mean & $57.5 \pm 7.0$ & $72.2 \pm 4.2$ & $67.9 \pm 2.9$ & $64.6 \pm 33$ & $588 \pm 38$ & $5.6 \pm 0.3$ \\
\hline
\end{tabular}

\section{Material AND Methods}

\subsection{Plant Material}

Bituminaria bituminosa is specie from the Leguminosae family which includes over 120 subspecies. It is a perennial and self-pollinating subspecies [12] and is widely distributed in the Mediterranean region [13], [14].This plant can grow in acidic soils with high ground water level [15]. The analysis of morphological traits separated B. bituminosa into six groups, crassiuscula, albomarginata, Tenerife, Mijas, Perdiz, and Alberquilla [6].This legume shrub is characterized by an average height ranged from 58 to $124 \mathrm{~cm}$. It's flowering period, was varied between of locations, 94 and 128 days. It was observed that all leaves were still green even at the stage of seed maturation. The average leaf numbers of plant taken at flowering stage showed a large variation between 50 and 596 [6]. 
The use of Bituminaria Bituminosa (L.) Stirton and Microbial Biotechnologies for Restoration of Degraded Pastoral Lands: the Case of The Middle Atlas of Morocco

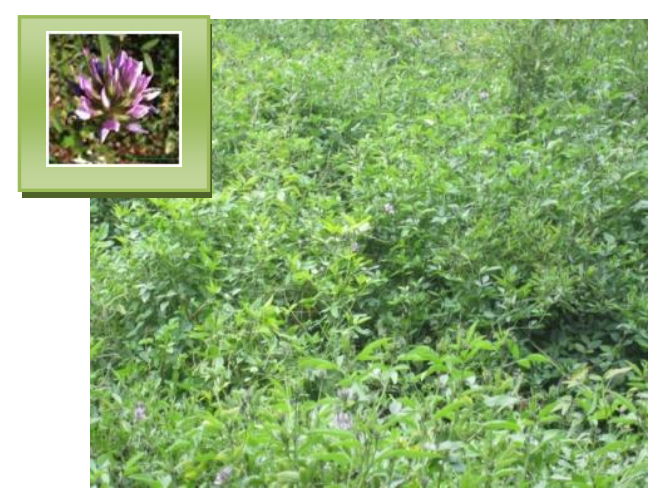

Fig1. Bituminaria bituminosa

\subsection{Isolation of Strain from Root Nodules}

A root nodule was crashed in $90 \mathrm{ml}$ of sterile distilled water. $2 \mathrm{ml}$ of the soil sample suspension was spread on Yeast Mannitol Agar (YMA) plates and incubated at $28{ }^{\circ} \mathrm{C}$. The colonies isolate typical of rhizobia were subjected to the Gram staining. Purity of the cultures was ensured by repeatedly streaking the bacteria on YMA and verifying a single type of colony morphology.

\subsection{Inoculation Preparation}

After their purification, the isolates were grown, separately, for $72 \mathrm{~h}$ in Yeast Mannitol Broth (YMB) at $28^{\circ} \mathrm{C}$ on a rotary shaker at $200 \mathrm{rpm}$. Growth was monitored by optical density measurement of the cell suspension at $600 \mathrm{~nm}$. Cell densities were related to viable cell numbers measured as cfu.ml-1 by standard plate count and the number of bacterial cells was adjusted to109cfu.ml-1.

\subsection{Plant Nodulation Test}

All isolates were tested for nodulation of B. bituminosa in plastic bags carried out in a greenhouse at the Faculty of Science, of Moulay Ismail University. Seeds were hand-sorted for size uniformity and freedom from damage, surface-disinfected by soaking in $1 \%$ mercuric chloride for 3 min followed by rinsing four times with sterile distilled water for 3, 5, 10 and $15 \mathrm{~min}$. Surface-disinfected seeds were placed on water agar plates and incubated at $28^{\circ} \mathrm{C}$ for 7 days to ensure their pre-germination. The experiment was conducted in plastic bags filled with $500 \mathrm{~g}$ of sterilized peat. Treatments were arranged in a randomized complete block with three replicate for each strain inoculated. The plants were watered twice a week. The treatments were maintained in a greenhouse under natural lighting and day/night temperatures of $25^{\circ} \mathrm{C} / 12,3^{\circ} \mathrm{C}$. Ten days after planting, we had applying the inoculations. Each inoculum was applied at the bottom of the shoot at the rate of $15 \mathrm{ml}$ (109cfu.ml-1) three times in order to enhance the infection chance.

\subsection{Description of Sites}

In order to carry out this study, three experimental sites were installed in the Central Middle Atlas, and more precisely in rangelands characterized by pastoral pressure that differs from one to another in the province of Ifrane. These sites were chosen differently in terms of climate and ecology. Some characteristics of the studied sites are illustrated in Table IV.

Table 5. Description of the Sites

\begin{tabular}{|c|c|c|c|c|c|}
\hline \multirow{2}{*}{ Site $\mathbf{n}^{\circ}$} & \multicolumn{2}{|c|}{ Geographical location } & Altitude (m) & $\begin{array}{c}\text { Annual rainfall } \\
\text { Average (mm) }\end{array}$ & climate \\
\cline { 2 - 3 } & $\mathbf{X}$ & $\mathbf{Y}$ & & 636 & Fresh Subhumid \\
\hline 01 & 536242 & 313213 & 1700 & 1122 & Cold Humid \\
\hline 02 & 532885 & 316934 & 1885 & 496 & Mild Semi arid \\
\hline 03 & 491516 & 300455 & 900 & & \\
\hline
\end{tabular}

\subsection{Methodological Approach}

The field experiment was installed after a production of Bituminaria bituminosa plants in the greenhouse of the Faculty of Sciences of Meknes. The area and number of plants planted in the three sites (1, 2 and 3) studied is respectively $300 \mathrm{~m} 2,50$ plants; $600 \mathrm{~m} 2,40$ plants; $240 \mathrm{~m} 2,30$ plants. Biomass assessment method Estimating biomass is an arduous process and often faced with 
The use of Bituminaria Bituminosa (L.) Stirton and Microbial Biotechnologies for Restoration of Degraded Pastoral Lands: The Case of the Middle Atlas of Morocco

difficulties in terms of the mass of labor required to establish individual biomass. To avoid the total cut of individuals, we chose the standard branch method [16] which consists in evaluating the total dry weight of Bituminaria bituminosa from the dry weight multiplication an average branch selected at each plant and the total number of branches at each plant.

The branch taken from each plant was freshly weighed and then dried in an oven at $60^{\circ} \mathrm{C}$ for 48 hours to calculate the dry weight.

In order to follow the development of Bituminaria bituminosa in the field, we calculated the phytovolume of each plant according to the following formula:

$$
V=\pi \times \mathbf{R}^{2 \times} \mathbf{H}
$$

With:

- $\quad V$ : Phytovolume of the plant in $\left(m^{3}\right)$

- $R$ : Mean radius of the plant in $(m)$

- H: Height of the plant. (M). [16].

To establish links between soil characteristics and Bituminaria bituminosa biomass production in the study sites, $200 \mathrm{~g}$ of soil samples were taken at each site from the soil organic layer $($ depth $<30 \mathrm{~cm}$ ). Samples were analysed for $\mathrm{pH}$, organic matter content and phosphorus (P2O5). These analyzes were carried out at the National Institute of Agricultural Research (INRA) in Rabat-Morocco.

\section{RESULTS AND DISCUSSION}

Table5. Soil Analyses

\begin{tabular}{|c|c|c|c|}
\hline Site $^{\circ}$ & $\mathbf{p H}$ & Organic Matter (\%) & $\mathbf{P}_{\mathbf{2}} \mathbf{O}_{\mathbf{5}} \mathbf{( p p m )}$ \\
\hline $\mathbf{1}$ & 7,6 & 7,6 & 107,7 \\
\hline $\mathbf{2}$ & 7,7 & 3 & 15,7 \\
\hline $\mathbf{3}$ & 7,5 & 3,2 & 113,1 \\
\hline
\end{tabular}

The soil analyzes in the sites studied show that site 01 is very rich in organic matter compared to other sites; in fact, this value exceeds those of other soils by $75 \%$, which has contributed to the importance of growth and development of plant biomass in this site.

\subsection{Dry Matter}

The determination of the dry biomass of Bituminaria bituminosa at the three sites shows that fodder production is estimated respectively at $511 \mathrm{~kg}$ MS / ha, $14.25 \mathrm{~kg} \mathrm{DM} / \mathrm{ha}$ and $23.64 \mathrm{~kg} \mathrm{DM} / \mathrm{ha}$ at sites 1,2 and 4. 3. Fig. 2 .This value seems very considerable in the first site and this can be explained by the favorable climatic conditions in this zone, as well as a better fertility of the soil in this site expressed by a very important organic matter content, added to a very high assimilable phosphorus concentration, improving the nutrition and growth of B. bituminosa plants.

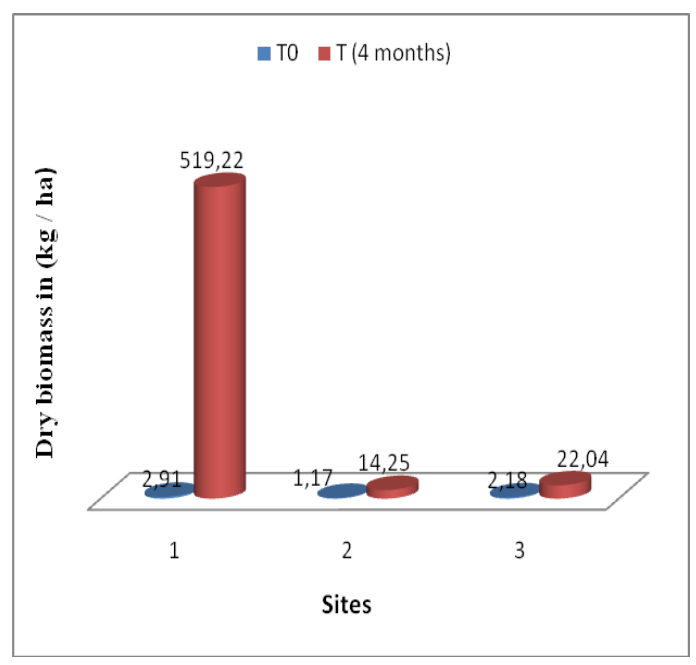

Fig2. Dry biomass in $(\mathrm{kg} / \mathrm{ha})$ 
The use of Bituminaria Bituminosa (L.) Stirton and Microbial Biotechnologies for Restoration of Degraded Pastoral Lands: the Case of The Middle Atlas of Morocco

\subsection{Phytovolume}

Consists of the evaluation-of-the-aerial-phytomass-and-the-productivity of B.bituminosa.

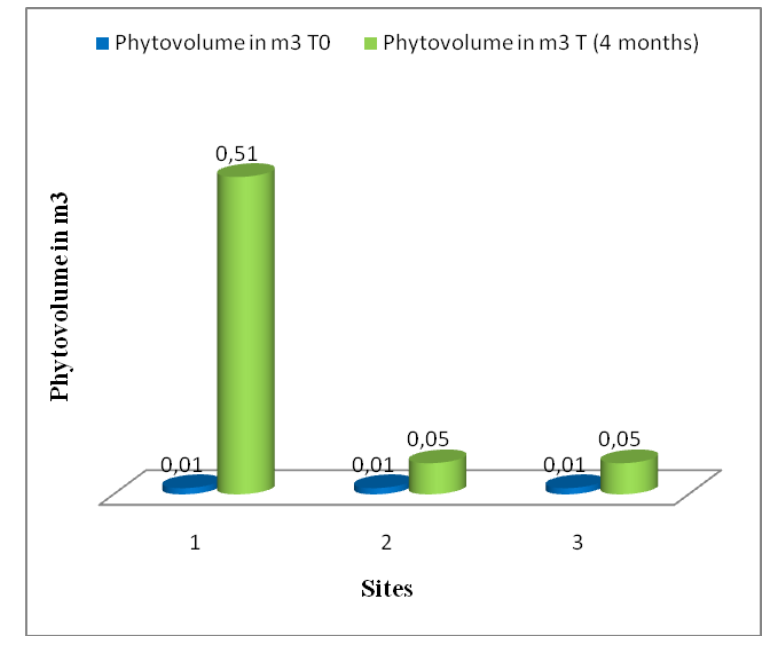

Fig3. Phytovolume in $m 3$

The results showed. Fig. 3 a significant increase in the phytovolume from the transplantation time to the fourth month growth in the field., in fact, the increase of the phytovolume is $196 \%, 20 \%$ respectively in the site 1 and the site 2 and 3. These results affirm those of the dry biomass found previously.

\section{CONCLUSION}

The use of multipurpose shrubs like Bituminaria combined with the microbial biotechnology can contribute significantly to resolve the problem of deforestation, land degradation and the heavy animal pressure on the forest by the overgrazing in particular.

The quantity and the quality of this shrub as a forage legume can also constitute an adapatative measure againt climate change by enhancing the carbon sequestration.

\section{ACKNOWLEDGMENT}

Our special thanks to the Regional Council of Fes-Meknes Region for financial support, and also the Regional Department of Forestry for the field facilities.

\section{REFERENCES}

[1] Haut-commissariat des eaux et forêts. Le Programme d'Action National de Lutte Contre la Désertification : Actualisation et adaptation aux spécificités zonales Rapport principale. (2013).

[2] Ferrera Cerrato, R., and Villerias SJ.The VA endomycorrhiza and its effect of the development of three arboreous legumes. In: Proceedings of the 6th North American Conference on Mycorrhizae Held at Bend, Oregon, USA (1985), p. 328.

[3] Reyes, O., and Trabaud L. Germination behaviour of 14 Mediterranean species in relation to fire factors: smoke and heat (2007).

[4] Reyes, O., and Trabaud L. Germination behaviour of 14 Mediterranean species in relation to fire factors: smoke and heat, Plant Ecology 202.(2009) : 113-121.

[5] Baxter B.J.M., van Staden J., Granger J.E., Brown N.A.C. Plant derived smoke and smoke extracts stimulate seed germination of the fire-climax grass Themeda triandra, Environ. Exp. Bot.(1994). 34, p.217-223

[6] Gulumser, E., Basaran, U., Acar, Z., Ayan, I., and Mut H. 2010. Determination of some agronomic traits of Bituminaria bituminosa accessions collected from Middle Black Sea Region. In : Porqueddu C. (ed.), Ríos S. (ed.). The contributions of grasslands to the conservation of Mediterranean biodiversity. Zaragoza : CIHEAM / CIBIO / FAO / SEEP, (Options Méditerranéennes : Série A. Séminaires Méditerranéens; n. 92) 10 5-108. (2010).

[7] Gutman, M., Perevolotsky A., and Sternberg M. Grazing effects on a perennial legume, Bituminaria bituminosa $(\mathrm{L}$.$) Stirton, in a Mediterranean rangeland. In: Options Méditerranéennes, Series Cahiers, 45. p.$ 299-303.(2000). 
The use of Bituminaria Bituminosa (L.) Stirton and Microbial Biotechnologies for Restoration of Degraded Pastoral Lands: The Case of the Middle Atlas of Morocco

[8] Yates, R.J., Real D., Revell C., and Howieson J.G. Developing inoculant quality root-nodule bacteria for Bituminaria bituminosa: a perennial pasture legume with potential for dryland agriculture. yIn: The 16th International Congress on Nitrogen Fixation, Montana (USA) (2009).

[9] Houerou, H.N. Browse in Northern Africa. International Livestock Centre for Africa, Addis Abeba.(1980).

[10] Mendez P., Fernandez, G. Especies arbustivas canarias como forraje para zonas aridas y semiaridas. In: Proceedings of the International Symposium on goat farming in arid zones. Coquimbo, Chile (1990).

[11] Ventura, M.R. Valor nutritivo de arbustos forrajeros. Ph.D. (1997).Dissertation. University of Las Palmas de Gran Canaria, Spain.

[12] Juan, A., Monino I., Correal E., Méndez P., and Crespo M.B. Comparación de lastasas de fructificación de Bituminaria bituminosa (Leguminosae) bajocondiciones de cultivo en canarias y la península Ibérica. In: Criado B.G., Cuidad A.G., de Aldana B.R.V. and Zabalgogeazcoa I. (eds). Pastos y Ganadería Extensiva, p. 111-115.(2004).

[13] Méndez, P., and Fernández M. Interés forrajero de las variedades de Bituminaria bituminosa (L.) Stirton ("tedera") de Canarias. In: XXX Reunión Científica de la Sociedad Española para el Estudio de los Pastos, San Sabastián (Spain), p. 264-272.(1990)

[14] Méndez, P., Fernández M. and Santos A. Variedades de Bituminaria bituminosa (L.) Stirton (Leguminosae) en el archipiéla gocanario. (1991).In: Pastos, 20, p. 157-166.

[15] Méndez, P. El heno de tedera (Bituminaria bituminosa): Un forraje apetecible para el caprino. (2000). In:3 Reunión Ibérica de Pastos y Forrajes, Galicia (Spain), p. 412-414.

[16] Bakkali, M., Qarro M., Diouri M., Barbero M., Bourbouze A. Phytomasse aérienne du cytise de Battandier (Argyrocytisus battandieri Maire) dans le Moyen Atlas marocain”, Fourrages, 162, 169-179. (2000).

Citation: O. Zennouhi, et.al, "The use of Bituminaria Bituminosa (L.) Stirton and Microbial Biotechnologies for Restoration of Degraded Pastoral Lands: The Case of the Middle Atlas of Morocco", International Journal of Research in Environmental Science (IJRES), vol. 5, no. 2, pp. 1-6, 2019. Available: DOI: http://dx.doi.org/ 10.20431 /2454-9444.0502001

Copyright:@ 2019 Authors. This is an open-access article distributed under the terms of the Creative Commons Attribution License, which permits unrestricted use, distribution, and reproduction in any medium, provided the original author and source are credited. 